\title{
High-density immobilization of a ginsenoside-transforming $\beta$-glucosidase for enhanced food-grade production of minor ginsenosides
}

\author{
Chang-hao Cui ${ }^{1,2} \cdot$ Byeong-Min Jeon ${ }^{3} \cdot$ Yaoyao Fu ${ }^{2} \cdot$ Wan-Taek $\mathrm{Im}^{4} \cdot$ Sun-Chang Kim ${ }^{1,3,5}$
}

Received: 23 February 2019 / Revised: 26 May 2019 / Accepted: 28 May 2019 / Published online: 9 July 2019

(C) The Author(s) 2019

\begin{abstract}
Use of recombinant glycosidases is a promising approach for the production of minor ginsenosides, e.g., Compound $\mathrm{K}(\mathrm{CK})$ and $\mathrm{F}_{1}$, which have potential applications in the food industry. However, application of these recombinant enzymes for food-grade preparation of minor ginsenosides are limited by the lack of suitable expression hosts and low productivity. In this study, Corynebacterium glutamicum ATCC13032, a GRAS strain that has been used extensively for the industrial-grade production of additives for foodstuffs, was employed to express a novel $\beta$-glucosidase (MT619) from Microbacterium testaceum ATCC 15829 with high ginsenosidetransforming activity. A cellulose-binding module was additionally fused to the N-terminus of MT619 for immobilization on cellulose, which is an abundant and safe material. Via one-step immobilization, the fusion protein in cell lysates was efficiently immobilized on regenerated amorphous cellulose at a high density (maximum $984 \mathrm{mg} / \mathrm{g}$ cellulose), increasing the enzyme concentration by 286 -fold. The concentrated and immobilized enzyme showed strong conversion activities against protopanaxadiol- and protopanaxatriol-type ginsenosides for the production of $\mathrm{CK}_{\text {and }} \mathrm{F}_{1}$. Using gram-scale ginseng extracts as substrates, the immobilized enzyme produced 7.59 $\mathrm{g} / \mathrm{L} \mathrm{CK}$ and $9.42 \mathrm{~g} / \mathrm{L} \mathrm{F}_{1}$ in $24 \mathrm{~h}$. To the best of our knowledge, these are the highest reported product concentrations of $\mathrm{CK}_{\text {and }} \mathrm{F}_{1}$, and this is the first time that a recombinant enzyme has been immobilized on cellulose for the preparation of minor ginsenosides. This safe, convenient, and efficient production method could also be effectively exploited in the preparation of food-processing recombinant enzymes in the pharmaceutical, functional food, and cosmetics industries.
\end{abstract}

Keywords Compound $\mathrm{K} \cdot$ Ginsenoside $\mathrm{F}_{1} \cdot$ Deglycosylation $\cdot$ Biotransformation $\cdot$ Corynebacterium glutamicum

Chang-hao Cui and Byeong-Min Jeon contributed equally to this work.

Electronic supplementary material The online version of this article (https://doi.org/10.1007/s00253-019-09951-4) contains supplementary material, which is available to authorized users.

Sun-Chang Kim

sunckim@kaist.ac.kr

1 Intelligent Synthetic Biology Center, 291 Daehak-Ro, Yuseong-Gu, Daejeon 305-701, Korea

2 The Key Laboratory of Biotechnology for Medicinal Plant of Jiangsu Province, Jiangsu Normal University, No. 101 Shanghai Road, Xuzhou, Jiangsu 221116, People's Republic of China

3 Department of Biological Sciences, Korea Advanced Institute of Science and Technology, 291 Daehak-Ro, Yuseong-Gu, Daejeon 305-701, Korea

4 Department of Biological Sciences, Hankyong National University, 327 Chungang-Ro, Anseong City, Kyonggi-Do 456-749, Korea

5 KAIST Institute for Biocentury, Korea Advanced Institute of Science and Technology, 291 Daehak-Ro, Yuseong-Gu, Daejeon 305-701, Korea

\section{Introduction}

Ginseng has been widely used to treat various diseases in East Asia for more than a thousand years and is increasingly used in foods and dietary supplements worldwide (Chung et al. 2011; Shi et al. 2013). Ginsenosides, triterpene saponins that are almost exclusively found in ginseng, are considered as the main active ingredients responsible for various pharmacological activities (Kim et al. 2013; Qi et al. 2010; Song et al. 2014). Six kinds of major ginsenosides ( $R e, \mathrm{Rg}_{1}, \mathrm{Rb}_{1}, \mathrm{Rb}_{2}, \mathrm{Rc}$, and $\mathrm{Rd}$ ) normally constitute more than $90 \%$ of the total ginsenosides in various parts of ginseng (Shi et al. 2013; Zhou et al. 2014). Most of the minor ginsenosides, which have fewer sugar moieties attached on aglycon, are absent or are present in smaller amounts than those of the major ginsenosides (Figure S1) (Shi et al. 2013; Zhou et al. 2014). Many minor ginsenosides have higher chemical reactivities than those of abundant major ginsenosides in raw materials (Smith et al. 2014; Wong et al. 2015). Among these minor ginsenosides, Compound K (CK) 
and $\mathrm{F}_{1}$ show important pharmacological effects, including antiinflammatory (Wang et al. 2015), anticancer (Cho et al. 2009; $\mathrm{Hu}$ et al. 2012), neuroprotective (Lee et al. 2013), anti-diabetic (Gu et al. 2013), and skin-healing effects (Lee et al. 2003; Lee 2018), supporting their potential application in the food and pharmaceutical industries.

However, $\mathrm{CK}$ and $\mathrm{F}_{1}$ are rare minor ginsenosides with low polarities and are absent or comprise less than $0.005 \%$ of raw ginseng or red ginseng (Park et al. 2013; Shi et al. 2013; Zhou et al. 2014). Thus, purifying large quantities of pure $C K$ and $F_{1}$ from the raw plant is extremely difficult and costly, resulting in a bottleneck in food applications. Microbial or enzymatic methods have been explored for $\mathrm{CK}$ and $\mathrm{F}_{1}$ preparation (Cui et al. 2016; Kim et al. 2011; Park et al. 2010). However, these methods exhibit low selectivity and poor productivity. As an alternative to preparing pharmacologically active $\mathrm{CK}$ and $\mathrm{F}_{1}$, recombinant enzymatic conversion methods have been explored to efficiently and specifically convert abundant major ginsenosides (Shin and Oh 2016).

Several recombinant glycosidases produce these two minor ginsenosides in gram-scale quantities from abundant major ginsenosides (An et al. 2017; Cui et al. 2013). Unfortunately, Escherichia coli is not a suitable expression host for preparing food-grade minor ginsenosides because it is not generally recognized as food- grade (GRAS) bacteria and also has the potential of generating endotoxins (Liu et al. 2016). Two recent studies have demonstrated the preparation of minor ginsenosides $F_{2}$ and $\mathrm{Rh}_{2}$-Mix from major ginsenosides using expression systems of GRAS host strains ( $\mathrm{Li}$ et al. 2016a; Siddiqi et al. 2017). Nevertheless, $C K$ or $F_{1}$ production has not been achieved using recombinant enzymes from GRAS hosts.

Furthermore, the production efficiencies of ginsenoside CK and $F_{1}$ by recombinant enzymes also require improvement. Enzyme modifications based on protein structure have been conducted to increase productivity, but limited improvements have been achieved (Shin et al. 2017). This issue can be addressed by modifying downstream processes, such as increments in the enzyme concentration, which could accelerate the reaction to reduce the precipitates of intermediates in minor ginsenosides preparation and reduce the reaction volume or time.

Conventional enzyme concentration methods, e.g., heating evaporation, freeze-drying, ultrafiltration, and chromatographic and precipitation separation, are limited by their high-energy consumption, long time processes, and activity damages (Shire et al. 2004). The adsorption method using a cellulose-binding module (CBM) to immobilize recombinant enzymes on cellulose is an emerging technique with many important advantages, such as low-energy consumption, simple operation, high affinity of binding, and minimum enzyme damage (Li et al. 2016b; Oliveira et al. 2015; Yu et al. 2017). Furthermore, the supporting material (cellulose) is an abundant and safe material that is broadly applied as a food additive (Eichhorn et al. 2009; Je et al. 2017). This immobilization method exhibits a high protein-binding capacity using regenerated amorphous cellulose (RAC), which can be simply made by phosphoric acid treatment (Hong et al. 2008; You and Zhang 2013).

In this study, a food-grade expression and immobilization method was developed to meet the demand for the enhanced production of $\mathrm{CK}$ and $\mathrm{F}_{1}$. For this purpose, we selected MT619 among 10 glycosidase candidates with high activity for transforming protopanaxadiol (PPD)-type ginsenoside mixtures (PPDGM) or protopanaxatriol (PPT)-type ginsenoside mixtures (PPTGM) into $\mathrm{CK}$ and $\mathrm{F}_{1}$, respectively. The enzymatic properties and substrate specificities of MT619 were investigated. The enzyme was fused with CBM (C3a) from Clostridium thermocellum and expressed as a recombinant enzyme (C3a-MT619) in Corynebacterium glutamicum ATCC13032 for immobilization on RAC with a high protein density. The treatment of PPDGM and PPTGM with the immobilized enzyme yielded gram-scale $\mathrm{CK}$ and $\mathrm{F}_{1}$ with high efficiency. These findings represent a substantial advance over the efficient production of minor ginsenosides using recombinant enzymes owing to the lack of studies of ginsenosidetransforming glycosidases immobilized on cellulose.

\section{Materials and methods}

\section{Chemicals and reagents}

Standards of various ginsenosides $\left(\operatorname{Rg}_{1}, \mathrm{Re}, \mathrm{Rb}_{1}, \mathrm{Rc}\right.$, and $\left.\mathrm{Rd}\right)$ used in the present study were purchased from Hongjiu Co., Ltd. (Dalian, China). GypXVII, GypLXXV, $\operatorname{Rg}_{3}(S), \operatorname{Rh}_{2}(S)$, $\mathrm{F}_{2}$, Compound $\mathrm{K}(\mathrm{CK}), \mathrm{PPD}, \mathrm{Rg}_{2}(S), \mathrm{Rh}_{1}(S)$, and PPT were prepared as described in our previous studies (Cui et al. 2014; Cui et al. 2017; Cui et al. 2013; Du et al. 2014). The other chemical reagents used were at minimum of extra pure grade.

\section{Synthesis and cloning of candidate glycosidases}

The bacterial strains and vectors employed for the expression of MT619 and C3a-MT619 are shown in Table S1. As codon preference differs among taxa, the 10 glucosidase genes were re-translated into DNA favoring the codon usage of C. glutamicum ATCC13032 to enhance expression in this organism and synthesized and cloned into pGEX4T-1 by Mutagenex Co. (Suwanee, GA, USA). The sequence for the codon-optimized mt619 gene was deposited into GenBank under accession number MK575514.

\section{Construction of MT619 and C3a-MT619 expression vectors}

DNA fragments of interest were amplified by polymerase chain reaction (PCR) with $P f u$ polymerase (Elpis-Biotech, 
Daejeon, Korea) and purified using gel-extraction kits obtained from Enzynomics Co. Ltd. (Seoul, Korea). Primers used in the present study are listed in Table S2. Five fragments were amplified and gel-purified: pEX backbone ( $\mathrm{P} 3$ and $\mathrm{P} 4), \mathrm{pH} 36$ backbone (P8 and P9), c3a (P5 and P6), mt619-1 (P1 and P2), c3a-mt619 (P10 and P11), and mt619-2 (P2 and P3). These fragments were joined by Gibson assembly (New England Biolabs, Ipswich, MA, USA) to form pEX-mt619 (pEX backbone and mt619-1), pEX-c3a-mt619 (pEX backbone, c3a, and mt619-2), and pH36-C3a-MT619 (pH 36 backbone and c3amt619). The resulting plasmids were transformed into C. glutamicum ATCC13032 by electro-transformation using the method described previously (Ruan et al. 2015).

\section{Characterization of MT619}

The protein concentrations in samples were determined using the Bradford reagent (Sigma, St. Louis, MO, USA) and the specific activity was determined using pNP- $\beta$-Dglucopyranoside (PNPGlc) as a substitute substrate at $37^{\circ} \mathrm{C}$. The reactions were monitored using a microplate reader BioRad Model 680 (Bio-Rad, Hercules, CA, USA) with kinetic mode, and the release of p-nitrophenol was measured at $405 \mathrm{~nm}$ every $5 \mathrm{~s}$. The effect and stability of $\mathrm{pH}$ and temperature, and metals and substrate preference on the enzymatic activity were determined as described previously (Cui et al. 2017).

Substrate preference of recombinant MT619 was determined using p-nitrophenyl (PNP) and o-nitrophenyl (ONP) glycosides as substrates (all from Sigma) at $37{ }^{\circ} \mathrm{C}$. The following substrates were examined: PNP- $\beta$-D-glucopyranoside, PNP- $\beta$-D-galactopyranoside, PNP- $\beta$-D-fucopyranoside, PNP$\mathrm{N}$-acetyl- $\beta$-D-glucosaminide, PNP- $\beta$-L-arabinopyranoside, PNP- $\beta$-D-mannopyranoside, PNP- $\beta$-D-xylopyranoside, PNP- $\alpha$-D-glucopyranoside, PNP- $\alpha$-L-arabinofuranoside, PNP- $\alpha$-L-arabinopyranoside, PNP- $\alpha$-L-rhamnopyranoside, PNP- $\alpha$-D-mannopyranoside, PNP- $\alpha$-D-xylopyranoside, ONP- $\beta$-D-glucopyranoside, ONP- $\beta$-D-galactopyranoside, ONP- $\beta$-D-fucopyranoside, and ONP- $\alpha$-D-galactopyranoside (all from Sigma).

\section{Biotransformation of the major ginsenosides using recombinant MT619}

Purified MT619 was used to examine its hydrolyzingspecificity to the sugar moieties attached to PPT-type ginsenosides ( $R e$ and $\left.\mathrm{Rg}_{1}\right)$ and PPD-type ginsenosides $\left(\mathrm{Rb}_{1}\right.$, Rd). The purified MT619 was reacted with $R e, R_{1}, R_{1}$, or $\mathrm{Rd}(2.0 \mathrm{mg} / \mathrm{mL}, \mathrm{pH} 7.0)$ in a shaking incubator at $37^{\circ} \mathrm{C}$. The ginsenosides in samples were extracted by butanol and were identified by thin-layer chromatography (TLC).

\section{RAC preparation}

RAC was prepared based on the method described previously (Hong et al. 2008). Briefly, $10 \mathrm{~g}$ of microcrystalline cellulose (SigmaCell 20) and $30 \mathrm{~mL}$ of distilled water were mixed to form a suspension. Two hundred milliliters of ice-cold $86 \%$ $\mathrm{H}_{3} \mathrm{PO}_{4}$ was carefully added to the mixture with stirring. After the cellulose solution turned transparent, it was placed on ice for one hour. Then, $800 \mathrm{~mL}$ ice-cold water was added with vigorous stirring by the addition of $200 \mathrm{~mL}$ at a time. The suspension mixture was centrifuged at $4000 \mathrm{~g}$ and $4{ }^{\circ} \mathrm{C}$ for $20 \mathrm{~min}$, and the supernatant was discarded. The cellulose pellet was washed four times with cold water to remove phosphoric acid. After neutralization using $2 \mathrm{M} \mathrm{Na}_{2} \mathrm{CO}_{3}$, the pellet was washed twice with water. The prepared RAC was stored at $4{ }^{\circ} \mathrm{C}$ as a 4 -g $\mathrm{RAC} / \mathrm{L}$ suspension with $0.2 \%$ sodium azide.

\section{Adsorption of C3a-MT619 on RAC}

To estimate the binding capacity of C3a-MT619 attached to the RAC, adsorption isotherm measurements were taken. A sequence of tubes containing $0.1-10 \mathrm{~mL}$ of C3a-MT619 cell lysate $(\mathrm{pH} 7.0)$ with a fixed concentration $(0.5 \mathrm{mg} / \mathrm{mL})$ was prepared. To each tube, $0.4 \mathrm{mg}$ of RAC was added and was incubated with shaking at $200 \mathrm{rpm}$ for $10 \mathrm{~min}$ at $25{ }^{\circ} \mathrm{C}$. The enzyme-immobilized RAC was centrifuged at $10,000 \mathrm{~g}$ for $5 \mathrm{~min}$ and the precipitate was washed twice with $1 \mathrm{~mL}$ of phosphate buffer $(50 \mathrm{mM}, \mathrm{pH} 7.0)$. The obtained cellulose was assayed for $\beta$-glucosidase activity adsorbed on the cellulose. The maximum enzyme adsorption capacity $\left(A_{\max }\right)$ of $\mathrm{RAC}$ was calculated by the Langmuir equation, as previously described (Hong et al. 2007). The $W_{\max }$ and $K_{\mathrm{p}}$ values were also calculated by mathematical methods (Bothwell and Walker 1995). The following equation was applied:

$E_{\mathrm{a}}=\frac{W_{\max } K_{\mathrm{p}} E_{\mathrm{f}}}{1+K_{\mathrm{p}} E_{\mathrm{f}}}$

$E_{\mathrm{a}}$ indicates adsorbed C3a-MT619 (mg/g RAC), $W_{\max }$ indicates the maximum C3a-MT619 adsorption per liter ( $\mathrm{mg} / \mathrm{g}$ RAC), and $E_{\mathrm{f}}$ indicates free C3a-MT619 (mg/g RAC).

\section{Preparation of recombinant MT619 from C. glutamicum ATCC13032}

For fed-batch cultivation and to obtain a high cell density of recombinant enzymes, defined and semidefined media supplemented with kanamycin $(30 \mathrm{mg} / \mathrm{L})$ were used to cultivate C. glutamicum ATCC13032 harboring pH36-C3a-MT619 in a 10-L stirred-tank reactor (Fermentec Co., Chungju, Korea) with a 6-L working volume at $400 \mathrm{rpm}$. As a seed culture, C. glutamicum ATCC13032 harboring pH36-C3a-MT619 was inoculated into $200 \mathrm{~mL}$ of defined medium containing 20 
$\mathrm{g} / \mathrm{L}$ glucose in a 1-L baffle flask and incubated at $30{ }^{\circ} \mathrm{C}$ for $20 \mathrm{~h}$ at $200 \mathrm{rpm}$. The medium consisted of $10 \mathrm{~g}$ of $\left(\mathrm{NH}_{4}\right)_{2} \mathrm{SO}_{4}, 3 \mathrm{~g}$ of $\mathrm{K}_{2} \mathrm{HPO}_{4}, 1 \mathrm{~g}$ of $\mathrm{KH}_{2} \mathrm{PO}_{4}, 2 \mathrm{~g}$ of urea, $2 \mathrm{~g}$ of $\mathrm{MgSO}_{4}, 200 \mu \mathrm{g}$ of biotin, $5 \mathrm{mg}$ of thiamine, $10 \mathrm{mg}$ of calcium pantothenate, $10 \mathrm{mg}$ of $\mathrm{FeSO}_{4}, 1 \mathrm{mg}$ of $\mathrm{MnSO}_{4}, 1 \mathrm{mg}$ of $\mathrm{ZnSO}_{4}, 200 \mu \mathrm{g}$ of $\mathrm{CuSO}_{4}$, and $10 \mathrm{mg}$ of $\mathrm{CaCl}_{2}$ per liter with $25 \mathrm{mg} / \mathrm{L}$ kanamycin.

The protein was constitutively expressed by the H36 promoter, as described previously (Yim et al. 2014). After the cell density reached an $\mathrm{OD}_{600}$ of 100 , the cells were harvested by centrifugation at $4000 \mathrm{~g}$ for $20 \mathrm{~min}$. The pellets were suspended in $50 \mathrm{mM}$ sodium phosphate buffer ( $\mathrm{pH} 7.0$ ); then, the cells were broken by sonication (Branson Digital Sonifier, Mexico City, Mexico). The cell debris was removed via centrifugation at $4000 \mathrm{~g}$ for $20 \mathrm{~min}$. The C3a-MT619 in cell lysate was absorbed by RAC with shaking for $15 \mathrm{~min}$ at $25^{\circ} \mathrm{C}$.

\section{Optimization of the substrate concentration}

$\mathrm{CK}$ and $\mathrm{F}_{1}$ production were evaluated using PPDGM and PPTGM. To determine the optimal concentration of substrates for the biotransformation reaction, enzyme-immobilized RAC was mixed with an equal volume of substrates at concentrations of $10-100 \mathrm{mg} / \mathrm{mL}$ at $37^{\circ} \mathrm{C}$. Samples were withdrawn at regular intervals and analyzed by HPLC.

\section{Scale-up $C_{K}$ and $F_{1}$ production}

The scaled-up transformation was performed in a shaking incubator at $200 \mathrm{rpm}$ and $37{ }^{\circ} \mathrm{C}$. The reaction started with 20 $\mathrm{mg} / \mathrm{mL}$ and $75 \mathrm{mg} / \mathrm{mL}$ substrates (PPDGM or PPTGM) as a final concentration by addition of immobilized C3a-MT619. Samples were analyzed by HPLC to determine the product concentrations of ginsenosides $\mathrm{CK}$ and $\mathrm{F}_{1}$.

\section{High-performance liquid chromatography analysis}

The HPLC analysis of samples in the present study was performed using an Agilent 1260 Infinity HPLC system (Agilent Co., Santa Clara, CA, USA). Separation of ginsenosides was conducted on a YMC ODS C18 column $(5 \mu \mathrm{m}, 250 \times 4.6$ $\mathrm{mm}$; YMC, Kyoto, Japan) with a guard column (Eclipse XDB C18, $5 \mu \mathrm{m}, 12.5 \times 4.6 \mathrm{~mm}$; Agilent Technologies, CA, USA). The gradient elution system consisted of water (A) and acetonitrile (B) using the following gradient program: 0-8 min, $32 \%$ B ; 8-12 min, 32-65\% B; 12-15 min, 65-100\% B; $15-$ $15.1 \mathrm{~min}, 100 \% \mathrm{~B} ; 15.1-25 \mathrm{~min}, 100-32 \% \mathrm{~B} ; 25-26 \mathrm{~min}$, $32 \% \mathrm{~B}$. The detection wavelength was set to $203 \mathrm{~nm}$ at a flow rate of $1.0 \mathrm{~mL} / \mathrm{min}$.

\section{TLC analysis}

TLC was conducted using $60 \mathrm{~F}_{254}$ silica gel plates (Merck, Darmstadt, Germany) and $\mathrm{CHCl}_{3}-\mathrm{CH}_{3} \mathrm{OH}-\mathrm{H}_{2} \mathrm{O}$ (65:35:10, $v / v / v)$ as the developing solution. The results were visualized by $10 \% \mathrm{H}_{2} \mathrm{SO}_{4}$ by heating at $110{ }^{\circ} \mathrm{C}$ for $5 \mathrm{~min}$.

\section{Results}

\section{Cloning of $\mathbf{1 0}$ glycosidase candidates for $\mathrm{CK}$ and $\mathrm{F}_{\mathbf{1}}$ production}

To identify highly productive enzymes, 19 uncharacterized family 3 glycosidases were chosen as candidates based on amino acid similarity by BLAST (blast.ncbi.nlm.nih.gov). In the phylogenetic tree (Zhang and Sun 2008), nine known enzymes that can transform the major ginsenosides $\mathrm{Rb}_{1}$ and $\mathrm{Rg}_{1}$ into $\mathrm{CK}$ and $F_{1}$ or $\mathrm{Rg}_{3}$ and $\mathrm{Rh}_{1}$ formed separate groups (Fig. 1). The ginsenoside-transforming characteristics of glycosidases are related to the properties of their amino acid sequences. Among the candidates, ten glycosidases (Table 1), which grouped with enzymes producing $\mathrm{CK}$ and $\mathrm{F}_{1}$, were selected for heterologous expression and characterization. The coding sequences of glycosidases were codon-optimized for expression in $C$. glutamicum ATCC13032, synthesized, and cloned into a pGEX4T-1 vector. These synthesized enzymes were expressed in E. coli and determined by SDS-PAGE (Figure S2). All candidates were successfully expressed in E. coli, except OJ521, and seven showed glucosidase activity against $\mathrm{pNP}-\beta$ glucopyranoside (PNPGlu), not including AS637 and BS642 (Table 1). Their ginsenoside-transforming activities were examined using $\mathrm{Rb}_{1}, \mathrm{Re}$, and $\mathrm{Rg}_{1}$ as substrates. Interestingly, the enzymes with $\mathrm{CK}$ and $\mathrm{F}_{1}$ producing abilities were grouped separately from $R h_{2}$ and $R h_{1}$ by the sequence-based phylogenetic tree. Based on TLC (Figure S3), all clones were able to hydrolyze $\mathrm{Rg}_{1}$ into $\mathrm{F}_{1}$, except BS642. Ginsenoside Re could be hydrolyzed by six glycosidases (TS608, IB608, CV626, CS617, and MS614) to PPT via $F_{1}$. Six enzymes (TS608, IB608, CV626, KA611, CS617, and AS637) showed $\mathrm{Rb} 1 \rightarrow \mathrm{GYP} 17 \rightarrow \mathrm{GYP} 75$ transforming activity and TS608 and CS617 produced CK by hydrolyzing the $\mathrm{C} 20$ outer glucose of Gyp75. MS614 and MT619 produced $F_{2}$ and CK that were different from other clones. The expression and activities of all clones are summarized in Table 1. These results also provide evidence for the amino acid sequence-activity relationships of ginsenoside-transforming glycosidases. We selected MT619, which exhibited the highest activity among all candidates, as a suitable enzyme for the production of $\mathrm{CK}$ and $\mathrm{F}_{1}$ from major ginsenosides.

\section{Expression of C3a-MT619 in C. glutamicum ATCC13032}

For high-density immobilization, a CBM (C3a) from C. thermocellum (Oliveira et al. 2015), was engineered at the N terminus of MT619 to construct C3a-MT619 with a 


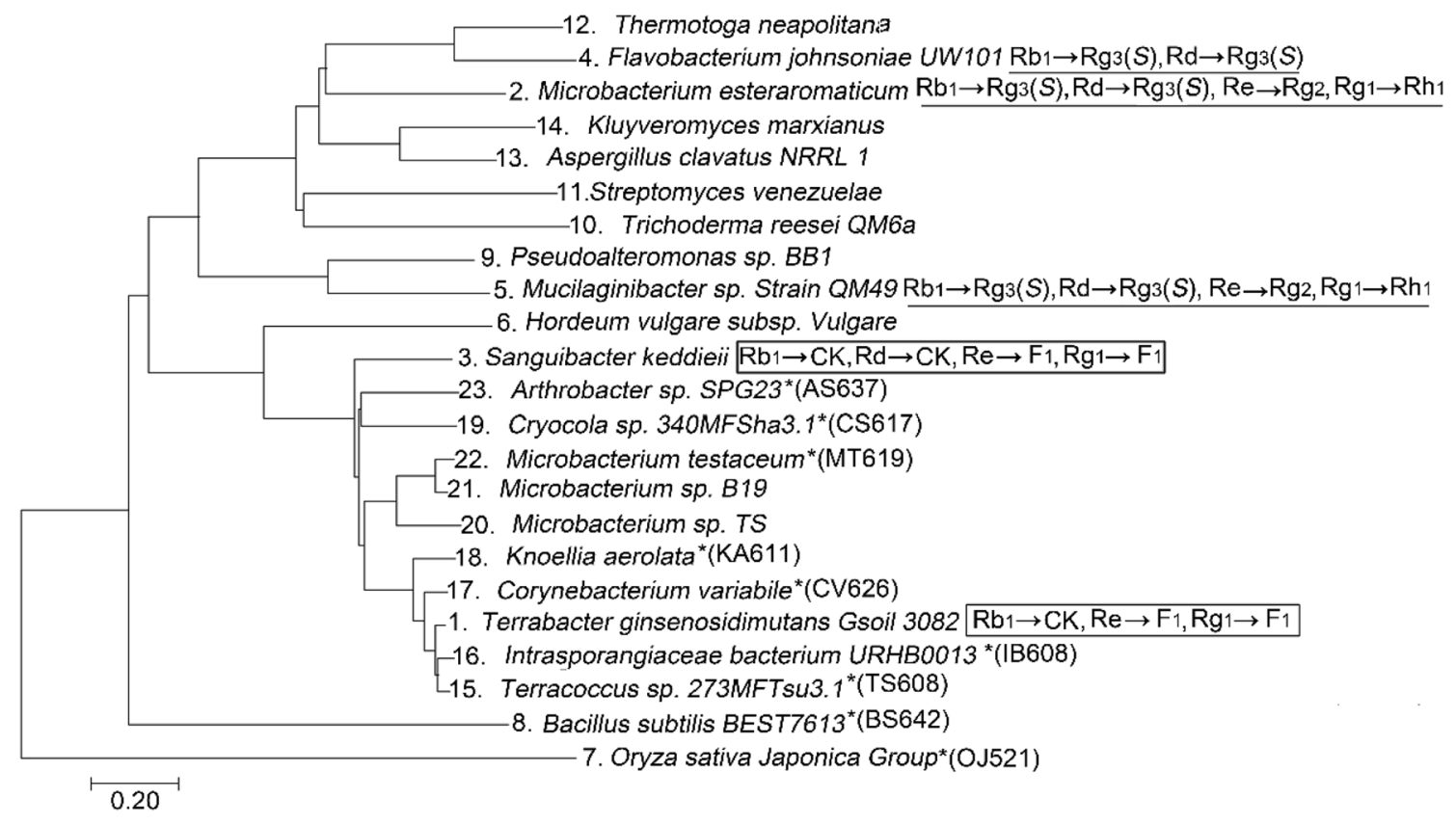

Fig. 1 Evolutionary relationships among the characterized and candidate glycosidases in glycoside hydrolase family 3 (GH3). Amino acid sequences of these proteins were retrieved from the CAZy and NCBI/ EMBL databases (accession numbers are indicated in Table 1). The

flexible linker $(\mathrm{G} 4 \mathrm{~S})_{2}$ to connect the two modules. The $m t 619$ and $c 3 a-m t 619$ genes consist of 1878 and 2376 bps and encode 625 and 791 amino acids, with molecular weights of 68.3 and $86.3 \mathrm{kDa}$. The genes were amplified by PCR and subcloned into the pEX4T-1 and $\mathrm{pH} 36$ vectors for heterologous expression in E. coli BL21 and C. glutamicum ATCC13032. C3a-MT619 was expressed continuously in C. glutamicum ATCC13032 by the promoter H36, which is efficient for heterologous expression (Yim et al. 2014). After cultivation for $24 \mathrm{~h}$, significant expression bands with the predicted molecular masses were observed (Fig. 2). Recombinant C3a-MT619 contains $1.41 \pm 0.03 \%$ of the total evolution was assumed using the neighbor-joining method in MEGA7 program (Kumar and Stecher 2016). The bar at the bottom represents 20 amino acid substitutions per 100 residues

proteins in the C. glutamicum ATCC13032 lysate, which is $21.5 \%$ of the expression level of the enzyme in E. coli BL21.

\section{Characterization of recombinant MT619}

MT619 and C3a-MT619 proteins were purified by Ni column and DEAE column chromatography. The predicted molecular mass ( 68.3 and $86.3 \mathrm{kDa})$ of the native $\beta$-glucosidase was validated by SDS-PAGE (Figure S4). Based on the examination of activity using PNPGlu, the recombinant C3a-MT619 expressed in C. glutamicum ATCC13032 had an enzyme

Table 1 Cloned glycosidases and their characteristics

\begin{tabular}{|c|c|c|c|c|c|c|c|}
\hline Name & Organism & Source & $\begin{array}{l}\text { pNP- } \beta \text { - } \\
\text { glucopyranoside } \\
\text { activity }\end{array}$ & $\mathrm{Rb}_{1}$ & $\mathrm{Re}$ & $\operatorname{Rg}_{1}$ & GenBank accession no. \\
\hline TS608 & Terracoccus sp. 273MFTsu3.1 & Bacteria & + & G75, CK & $\mathrm{F}_{1}, \mathrm{PPT}$ & $\mathrm{F}_{1}$ & WP_020141869.1 \\
\hline IB608 & Intrasporangiaceae bacterium & Bacteria & + & G17, G75 & $\mathrm{F}_{1}, \mathrm{PPT}$ & $\mathrm{F}_{1}$ & WP_026862722.1 \\
\hline CV626 & Corynebacterium variabile & Bacteria & + & G17, G75 & $\mathrm{F}_{1}, \mathrm{PPT}$ & $\mathrm{F}_{1}$ & WP_030201081 \\
\hline KA611 & Knoellia aerolata & Bacteria & + & $\mathrm{G} 17, \mathrm{G} 75$ & - & $\mathrm{F}_{1}$ & WP_035939434.1 \\
\hline CS617 & Cryocola sp. 340MFSha3.1 & Bacteria & + & $\mathrm{G} 75, \mathrm{CK}$ & $\mathrm{F}_{1}, \mathrm{PPT}$ & $\mathrm{F}_{1}$ & WP_020076619.1 \\
\hline AS637 & Arthrobacter sp. SPG23 & Bacteria & Weak & G75 & - & $\mathrm{F}_{1}$ & WP_043484882.1 \\
\hline MS614 & Microbacterium sp. TS- & Bacteria & + & $\mathrm{F}_{2}, \mathrm{CK}$ & $\mathrm{F}_{1}, \mathrm{PPT}$ & $\mathrm{F}_{1}$ & WP_023951833.1 \\
\hline MT619 & Microbacterium testaceum & Bacteria & + & $\mathrm{F}_{2}, \mathrm{CK}$ & $\mathrm{F}_{1}, \mathrm{PPT}$ & $\mathrm{F}_{1}, \mathrm{PPT}$ & WP_013585536.1 \\
\hline BS642 & Bacillus subtilis BEST7613 & Bacteria & - & - & - & - & BAM49096.1 \\
\hline OJ521 & Oryza sativa Japonica Group & Plant & - & - & PPT & - & AAN01354.1 \\
\hline
\end{tabular}




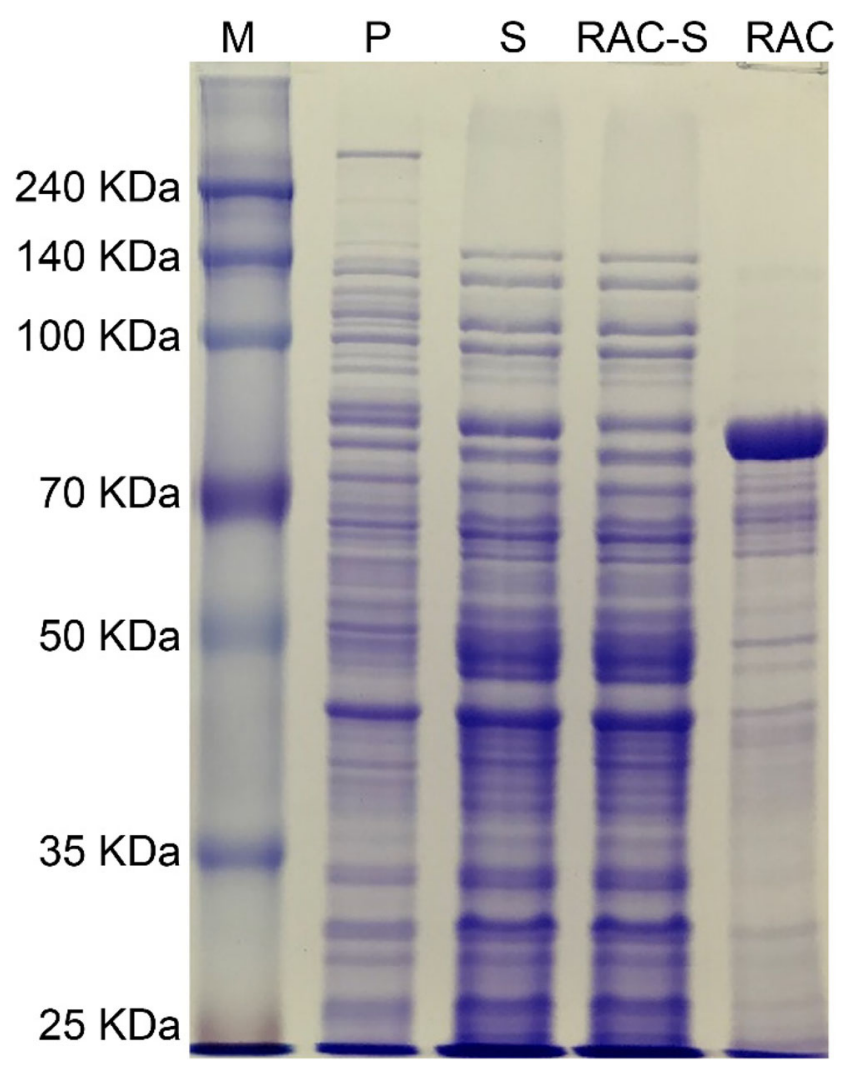

Fig. 2 SDS-PAGE analysis of the C. glutamicum ATCC13032 cell extracts containing the recombinant proteins and RAC pull-down proteins. Lane M, protein marker; Lanes S, soluble cell extract containing C3a-MT619; Lanes P, precipitant of the cell extract, respectively; Lane RAC-S, the supernatant after immobilization; Lane RAC, RAC adsorbed C3a-MT619

activity of $61.9 \%$ of the MT619 heterologously expressed in E. coli.

The optimum $\mathrm{pH}$ and temperature were examined using purified MT619. The effect of $\mathrm{pH}$ on enzymatic activity was determined using $2.0 \mathrm{mM}$ PNPGlc as a substrate. The $\mathrm{pH}$ stability of recombinant C3a-MT619 was determined by measuring enzymatic activity after incubation in each buffer at $4{ }^{\circ} \mathrm{C}$ for $12 \mathrm{~h}$. MT619 was relatively stable from $\mathrm{pH} 6.0$ to 8.0 and had optimal activity at $\mathrm{pH} 7.0$; from $\mathrm{pH} 9.0$, the enzyme activity decreased rapidly and at $\mathrm{pH} 5.0$, the enzyme activity reduced to $54.0 \%$ (Fig. 3a). The effect of temperature on enzymatic activity was tested by incubating the enzyme with an optimal $\mathrm{pH}$ buffer containing $2.0 \mathrm{mM}$ pNPGlc for $5 \mathrm{~min}$. The optimal temperature for enzyme activity was $45^{\circ} \mathrm{C}$; at $30^{\circ} \mathrm{C}$ and $37^{\circ} \mathrm{C}$, the enzyme had a relative activity of $70.3 \%$ and $88.6 \%$, respectively. Recombinant MT619 was relatively stable at temperatures lower than $30{ }^{\circ} \mathrm{C} .76 .3 \%$ and $54.9 \%$ of enzyme activity were retained after incubation for $2 \mathrm{~h}$ at $37^{\circ} \mathrm{C}$ and $45^{\circ} \mathrm{C}$, respectively, and no activity was detected above $55^{\circ} \mathrm{C}$ (Fig. 3b). Though MT619 has the highest activity at $45{ }^{\circ} \mathrm{C}$, the ginsenosidetransforming reaction was conducted at $37{ }^{\circ} \mathrm{C}$ to extend the stable transformation activity.
The effects of chemical reagents and metal ions on MT619 activity were determined using a concentration of $10 \mathrm{mM}$. The enzyme activity was not affected by $\beta$-mercaptoethanol, $\mathrm{Ca}^{2+}$, $\mathrm{Na}^{+}, \mathrm{K}^{+}$, and $\mathrm{Mg}^{2+}$; however, activity was lost in the presence of $\mathrm{Cu}^{2+}, \mathrm{Hg}^{2+}$, and $\mathrm{Zn}^{2+}$. EDTA did not affect its activity, indicating that divalent cations are not necessary for the enzyme activity. MT619 was significantly inhibited by $\mathrm{Co}^{2+}$ and $\mathrm{Mn}^{2+}$. No significant positive effects on the activity of the MT619 were found for the tested ions and agents (Table S3).

The glycoside specificity of MT619 was examined using PNP and ONP glycosides. MT619 was only active against the glucose moiety of PNP- $\beta$-D-glucopyranoside and ONP- $\beta$-Dglucopyranoside. It showed maximum activity towards PNP- $\beta$-D-glucopyranoside and $28.7 \%$ relative activity towards ONP- $\beta$-D-glucopyranoside.

\section{Ginsenoside-transformation activity of MT619}

MT619 could clearly transform four major ginsenosides (Re, $\mathrm{Rg}_{1}, \mathrm{Rb}_{1}$, and $\mathrm{Rd}$ ), as evidenced by the Rf values in a TLC analysis (Fig. 4). The proposed biotransformation pathways by MT619 for the PPD ginsenosides are $\mathrm{Rb}_{1} \rightarrow$ GypXVII(G17) $\rightarrow$ GypLXXV(G75) \& $\mathrm{F}_{2} \rightarrow \mathrm{CK} \rightarrow \mathrm{PPD} ; \mathrm{Rd} \rightarrow$ $\mathrm{F}_{2} \rightarrow \mathrm{CK} \rightarrow \mathrm{PPD} ; \mathrm{Re} \rightarrow \mathrm{F}_{1} \rightarrow \mathrm{PPT} ; \mathrm{Rg}_{1} \rightarrow \mathrm{F}_{1} \rightarrow \mathrm{PPT}$ (Fig. 5). This enzyme has less hydrolytic activity against the glucose at the C20 position, which may result in the production of $\mathrm{CK}$ and $\mathrm{F}_{1}$ from the abundant higher polarity ginsenosides. The transforming pathways are similar to the reported ginsenoside-transforming glucosidases (An et al. 2010; Shin et al. 2017). However, MT619 showed the highest $F_{1}$ production activity, which was 7.4 times higher than that of BgpA, used for the gram-scale production of this rare minor ginsenoside (An et al. 2017). Interestingly, we also found an unexpected band (MT1) whose Rf value was higher than those that of $\operatorname{Rg}_{1}$ and $\operatorname{Rg}_{2}$ (Fig. 4). This may represent the trans-glycosylated products of Re, produced by MT619, whose molecular weight is 784.7 , as determined by MS/MS detection in positive electrospray ionization mode. The molecular structure of MT1 and the transglycosylation activity of MT619 would be analyzed in future studies.

\section{Adsorption of C3a-MT619 on RAC}

CBMs are often fused to the partner proteins to assist their production and purification (Oliveira et al. 2015). The expressed C3a-MT619 was adsorbed on the surface of RAC, which has a much larger external surface area than that of microcrystalline cellulose (Hong et al. 2008). The crude cell lysates of C3a-MT619 were obtained by sonication of the cell pellets and mixed with RAC; thus, C3a-MT619 was adsorbed on the surface of cellulosic material as revealed by SDSPAGE analysis (Fig. 2). The adsorption curves of the immobilized C3a-MT619 enzyme detected by glucosidase 
Fig. 3 Effects of $\mathrm{pH}(\mathbf{a})$ and temperature (b) on the $\beta$ glucosidase activity and enzyme stability of MT619

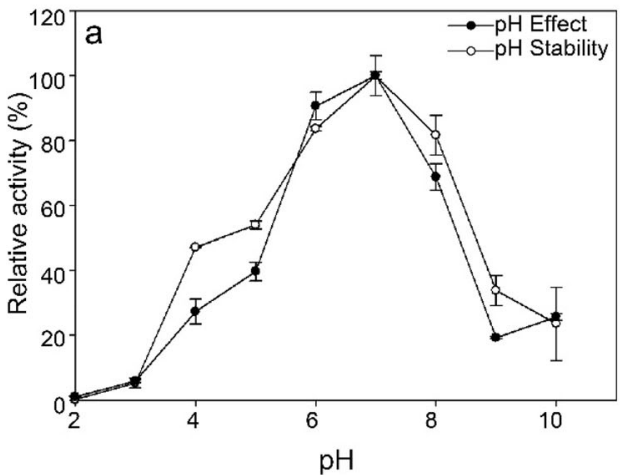

activity obeyed the Langmuir isotherms, suggesting single layer adsorption (Fig. 6). The maximum adsorption capacity of the fusion enzyme was $984 \mathrm{mg} / \mathrm{g} \mathrm{RAC}$, and the maximum enzyme concentration on RAC is approximately $78.7 \mathrm{mg} / \mathrm{mL}$ RAC (condensed by centrifugation at $10,000 \mathrm{~g}$ for $5 \mathrm{~min}$ ), which is 286 times greater than the cell lysate concentration.

Scale-up absorption was conducted using $5000 \mathrm{~mL}$ of cell lysate and $50 \mathrm{~mL}$ of RAC. $66.0 \%$ of C3a-MT619 in the cell lysate was immobilized on RAC by shaking for $10 \mathrm{~min}$, resulting in a 61.8-fold increase in concentration compared with the cell lysate. The immobilized concentration of C3a-
MT619 on RAC was $217 \mathrm{mg} / \mathrm{g}$ RAC $(17.3 \mathrm{mg} / \mathrm{mL}$ RAC, condensed by centrifugation at $10,000 \mathrm{~g}, 5 \mathrm{~min}$ ), and SDSPAGE showed that some unspecific proteins in C. glutamicum ATCC13032 were co-immobilized on cellulose (Fig. 2); these were consistent with previous results ( $\mathrm{Li}$ et al. 2016b). The immobilized C3a-MT619 retained over $78.0 \%$ of its activity after successive washing with 10 volumes of buffer repeated 10 times. Although the immobilization of C3a-MT619 was quite stably attached to RAC in this experiment, the re-usability of the immobilized enzymes is limited by the co-precipitation of the generated $\mathrm{CK}$ and $\mathrm{F}_{1}$.
Fig. 4 Biotransformation of $\mathrm{Rb}_{1}$, $\mathrm{Rd}, \mathrm{Re}$, and $\mathrm{Rg}_{1}$ by purified MT619 $(0.1 \mathrm{mg} / \mathrm{mL})$ analyzed by TLC. S1, S2, S3, and S4, ginsenoside standards; $\mathrm{C} 1$, substrate Re; 1 and 2,

biotransformation of Re by purified MT619 for $2 \mathrm{~h}$ and $4 \mathrm{~h}$, the suspected trans-glycosylated product-MT1 is indicated with an arrow; $\mathrm{C} 2$, substrate $\mathrm{Rg} 1 ; 3$ and 4, biotransformation of $\mathrm{Rg} 1$ by MT619 for $2 \mathrm{~h}$ and $4 \mathrm{~h}$; C3, substrate $\mathrm{Rb} 1 ; 5,6,7,8$, and 9, biotransformation of Rb1 by MT619 for $0.01 \mathrm{~h}, 1 \mathrm{~h}, 2 \mathrm{~h}, 6 \mathrm{~h}, 12 \mathrm{~h}$, and $24 \mathrm{~h} ; \mathrm{C} 4$, substrate Rd; 10, 11, 12 , 13 , and 14 , biotransformation of Rd by MT619 for 1 h, 2 h, 6 h, 12 $\mathrm{h}$, and $24 \mathrm{~h}$. MT1, the suspected transglycosylated product, is indicated by a blue arrow in 2
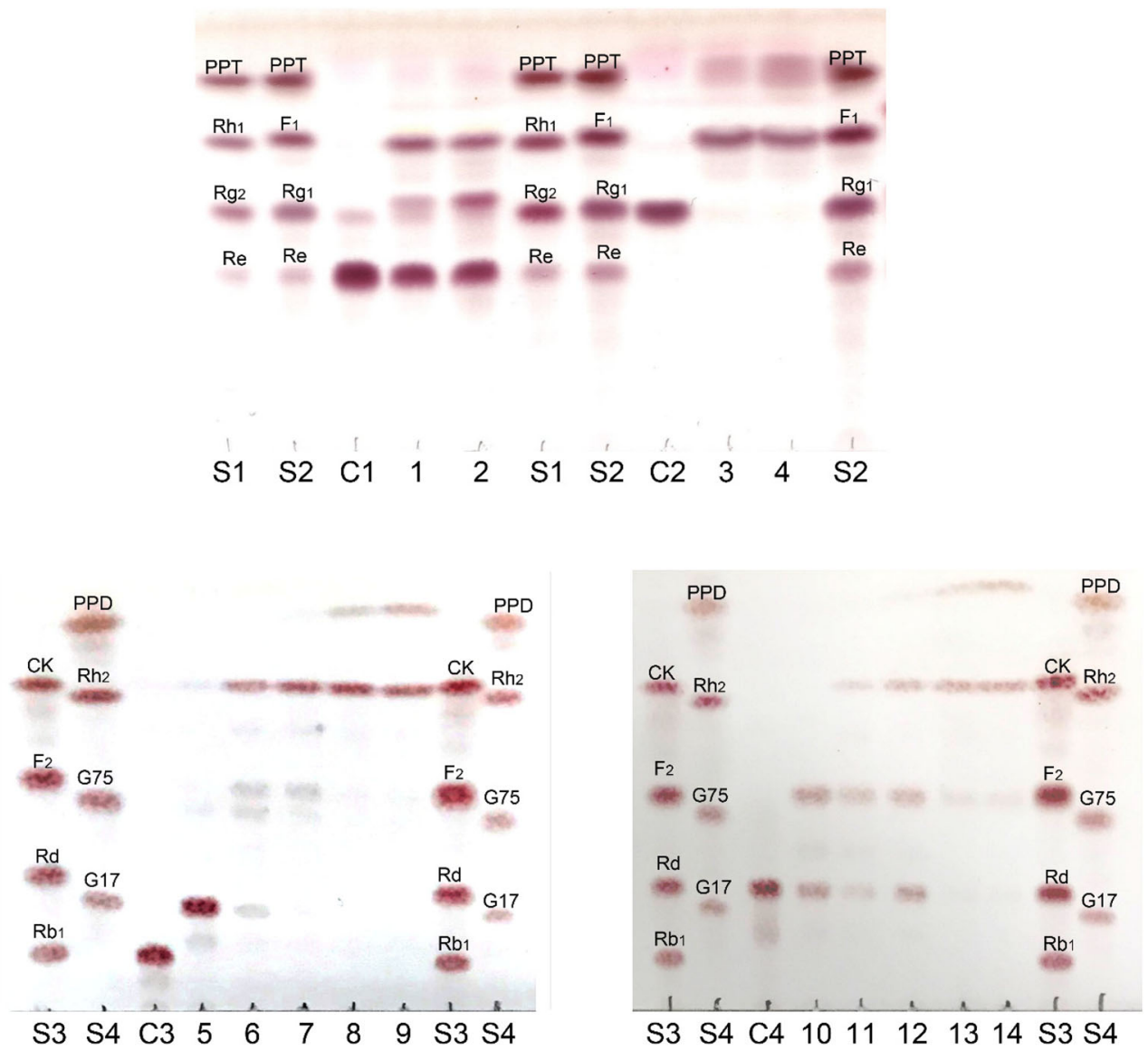


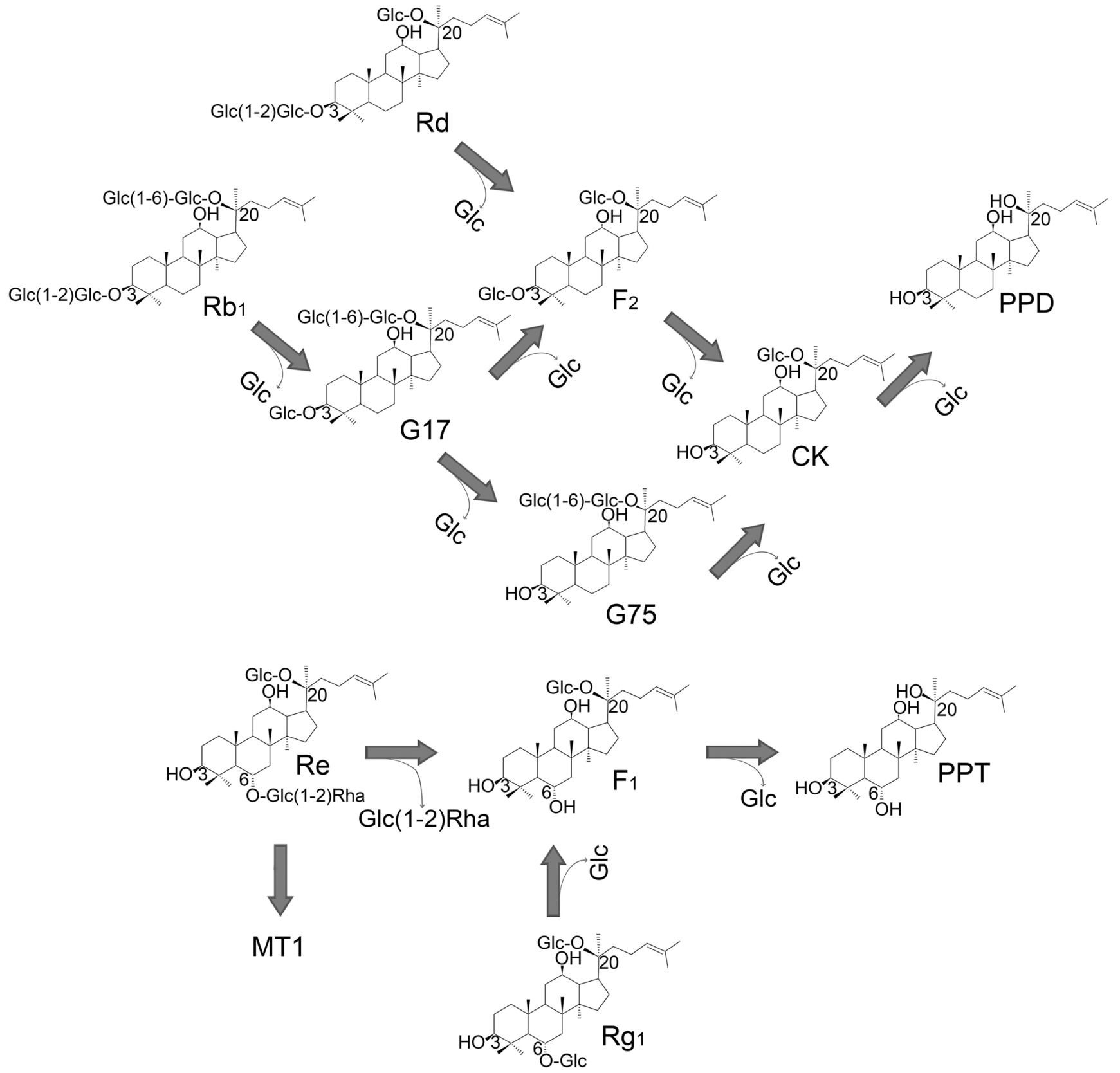

Fig. 5 Transforming pathways of ginsenosides $\mathrm{Rb}_{1}, \mathrm{Rd}, \mathrm{Re}$, and $\mathrm{Rg}_{1}$ and their metabolites hydrolyzed by recombinant MT619

\section{Optimization of substrate concentration for production of $C_{K}$ and $F_{1}$}

The enzyme reactions were performed using immobilized C3a-MT619 (217 mg/g RAC), and PPTGM and PPDGM were used as substrates owing to their relative abundance in crude ginseng extracts (Wan et al. 2008; Zhao et al. 2007). Various substrate concentrations of PPTGM and PPDGM $(10-100 \mathrm{mg} / \mathrm{mL})$ were examined to determine the appropriate reaction conditions for reduced reactor volumes and costs (Fig. 7a, b). The immobilized enzyme transformed $20 \mathrm{mg} /$ $\mathrm{mL}$ PPDGM into CK with $8.25 \mathrm{mg} / \mathrm{mL}$ product concentration
(Fig. 7a). PPDGM (10 mg/mL) reached its peak concentration after $18 \mathrm{~h}$ and decreased when CK (the final product) was transformed into PPD by C3a-MT619. Higher concentrations of PPDGM $(>20 \mathrm{mg} / \mathrm{mL})$ reduced productivity. Though a substrate concentration of $50 \mathrm{mg} / \mathrm{mL}$ resulted in similar CK concentrations, we choose $20 \mathrm{mg} / \mathrm{mL}$ for the scaling-up the productivity. The concentration of $\mathrm{F}_{1}$ was increased in proportion to the substrate concentration, and the maximum product concentration of $F_{1}$ was $9.14 \mathrm{mg} / \mathrm{mL}$ using $100 \mathrm{mg} / \mathrm{mL}$ PPTGM for $24 \mathrm{~h}$ (Fig. 7b). Owing to the advantages of using small quantities of enzymes and complete conversion of substrates, the PPDGM and PPTGM concentrations of $20 \mathrm{mg} / \mathrm{mL}$ 


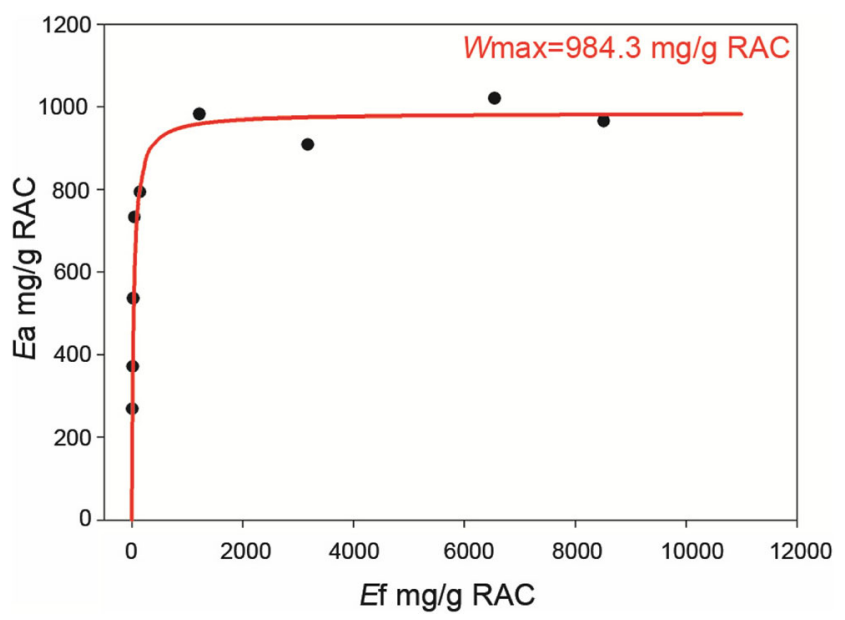

Fig. 6 Various amounts of C3a-MT619 protein adsorption on a fixed amount of RAC at $25^{\circ} \mathrm{C}$. The Langmuir equation was used to calculate the $A_{\max }$ value

and $75 \mathrm{mg} / \mathrm{mL}$, respectively, were adopted for the scaled-up production of $\mathrm{CK}$ and $\mathrm{F}_{1}$.

\section{Mass production of $\mathrm{CK}_{\text {and }} \mathrm{F}_{\mathbf{1}}$ using immobilized C3a-MT619}

Commercially available PPDGM and PPTGM were used as substrates for the mass production of $\mathrm{CK}$ and $\mathrm{F}_{1}$ by the
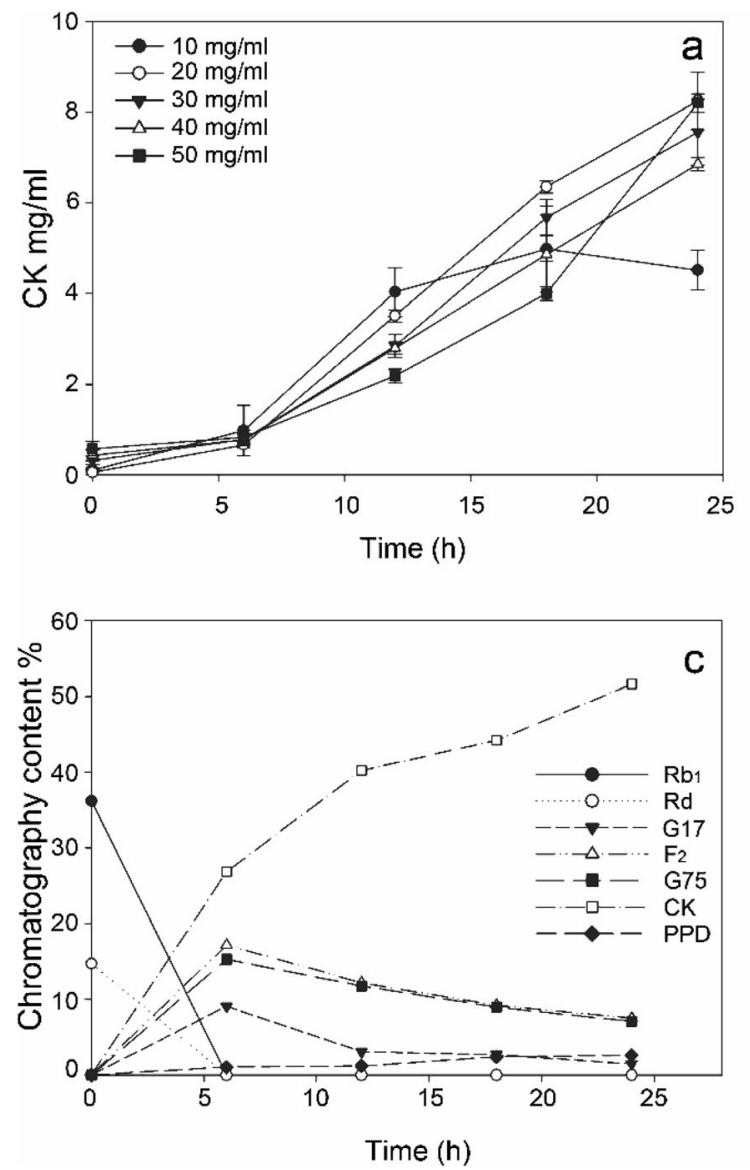

immobilized enzymes with an enzyme-substrate volume ratio of 1:5 for $24 \mathrm{~h}$ (Fig. 7c, d). PPTGM (40 mL; $75 \mathrm{mg} / \mathrm{mL}$ ) was used to produce ginsenoside $F_{1}$ by the conversion of the immobilized C3a-MT619. A total of $54.3 \%$ of $\mathrm{Rg}_{1}$ and $\mathrm{Re}$ was transformed in $24 \mathrm{~h}$ with $9.42 \mathrm{~g} / \mathrm{L} \mathrm{F}_{1}$ product. The reaction for CK production consisted of $30 \mathrm{~mL}$ of C3a-MT619 immobilized RAC and $3 \mathrm{~g}$ of PPDGM (substrate, $20 \mathrm{mg} / \mathrm{mL}$ ) in $150 \mathrm{~mL}$ of $50 \mathrm{mM}$ sodium phosphate buffer. As shown in Fig. 7c, Rb $b_{1}$ and $\mathrm{Rd}$ in PPDGM were completely converted by the immobilized C3a-MT619 in $6 \mathrm{~h}$. CK was produced at a concentration of $7.86 \mathrm{~g} / \mathrm{L}$ in $24 \mathrm{~h}$, with a $79.2 \%$ molar yield. Samples for $\mathrm{CK}$ and $\mathrm{F}_{1}$ production drawn and analyzed by HPLC are shown in Fig. 8. The produced CK and $F_{1}$ were isolated from the reaction mixture using macroporous resins. Finally, $1.38 \mathrm{~g}$ and $1.59 \mathrm{~g}$ of $\mathrm{CK}$ and $\mathrm{F}_{1}$ products with $51.6 \%$ and $25.2 \%$ chromatographic purity were produced.

\section{Discussion}

Recent studies have focused on the many pharmacological effects of ginsenoside $\mathrm{CK}$ and $\mathrm{F}_{1}$ owing to their potential food, cosmetics, and pharmaceutical applications. $\mathrm{F}_{1}$ is a potential drug for pigmentary disorders, atherosclerosis, and aging-
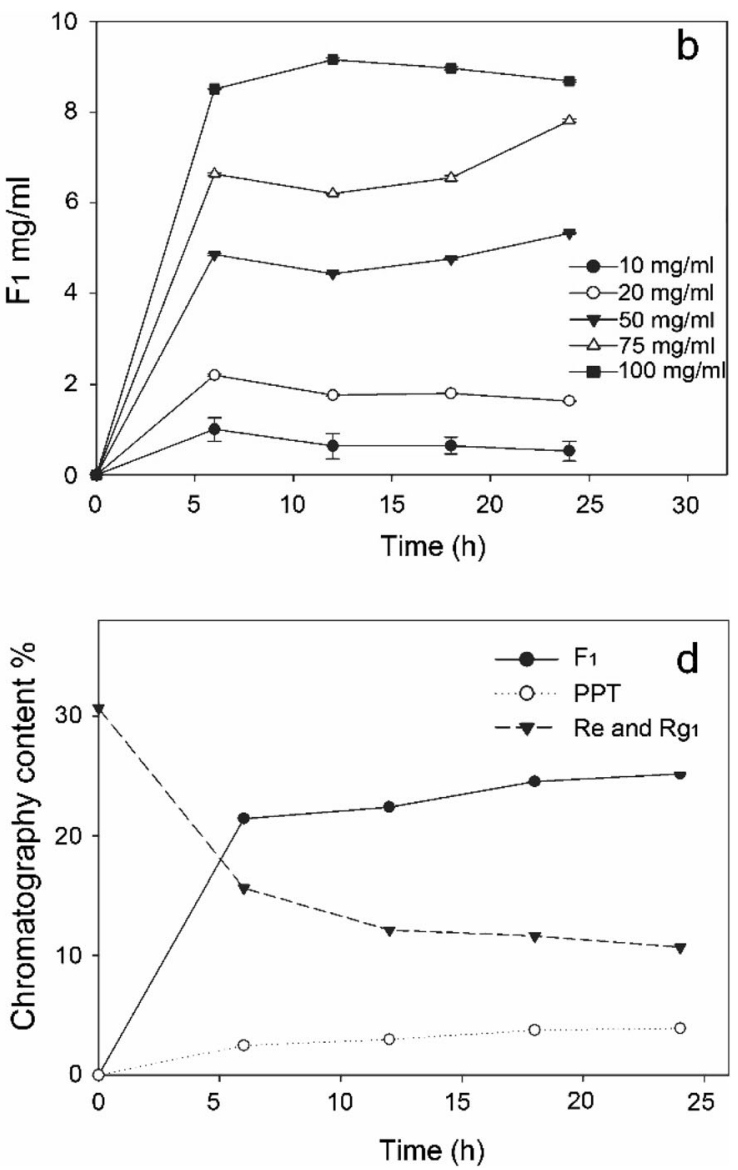

Fig. 7 Effect of the substrate concentration on the production of CK (a) and $\mathrm{F}_{1}(\mathbf{b})$ using immobilized C3a-MT619, and scale-up productions $\left(\mathrm{CK}(\mathbf{c})\right.$; $\left.\mathrm{F}_{1}(\mathbf{d})\right)$ 


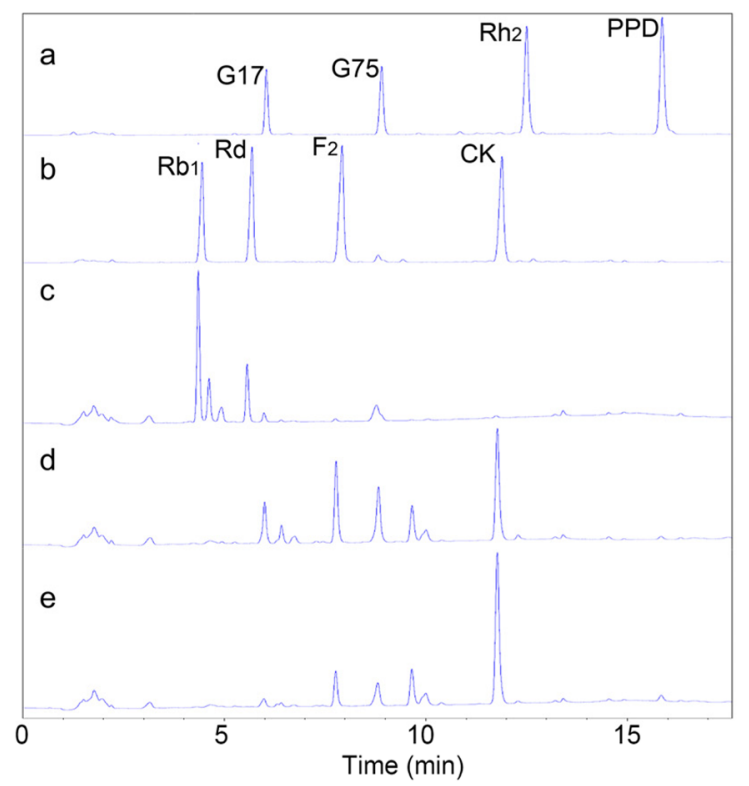

Fig. 8 HPLC analysis of the transformation of ginsenosides using immobilized C3a-MT619. a Ginsenoside standards (G17, G75, $\mathrm{Rh}_{2}$, PPD). b Ginsenoside standards $\left(\mathrm{Rb}_{1}, \mathrm{Rd}, \mathrm{F}_{2}, \mathrm{CK}\right)$. c PPDGM. d CK produced after $6 \mathrm{~h}$ of reaction of immobilized C3a-MT619 with

related diseases (Hou et al. 2018; Lee et al. 2018; Qin et al. 2017). CK showed anticarcinogenic effects (Yang et al. 2015), outstanding skin anti-aging, anti-diabetes, and anti-arthritis effects (Chen et al. 2015; Lee et al. 2018; Wei et al. 2015). A human trial confirmed that CK is safe and well tolerated over the treatment period (Chen et al. 2017a), and pre-clinical experiments and early clinical trials have also been performed (Chen et al. 2017b; Zhou et al. 2018). However, the contents of minor ginsenosides in ginseng functional food products are low (less than 5.0\%) (Ha et al. 2013; Sun et al. 2009).

Highly efficient and specific enzymatic transformation may be a promising method for minor ginsenoside preparation, especially using recombinant enzymes. In the last decade, the CK productivity from ginseng extracts increased to $4.2 \mathrm{mg} / \mathrm{mL}$, which was accomplished using two recombinant glycosidases by Shin et al (Shin et al. 2016a). Similarly, $F_{1}$ productivity increased to $6.7 \mathrm{mg} / \mathrm{mL}$ using a recombinant $\beta$ glucosidase from Terrabacter ginsenosidimutans Gsoil $3082^{\mathrm{T}}$ by our research group (An et al. 2017). However, both these studies used $E$. coli as host for enzyme preparation.

There is limited use of recombinant proteins from E. coli as food additives because $E$. coli is a non-GRAS species (Burdock and Carabin 2004). The use of C. glutamicum ATCC13032 has been suggested for application in production of food-grade material as it is an endotoxin-free GRAS strain, with many biotechnological advantages - easy gene manipulation, and growth rate, requirement of inexpensive media, and many industrial-grade food applications ( $\mathrm{Lv}$ et al. 2012; Shin et al. 2016b; Yim et al. 2014). Hyaluronic acid and recombinant isomerase have been produced by recombinant

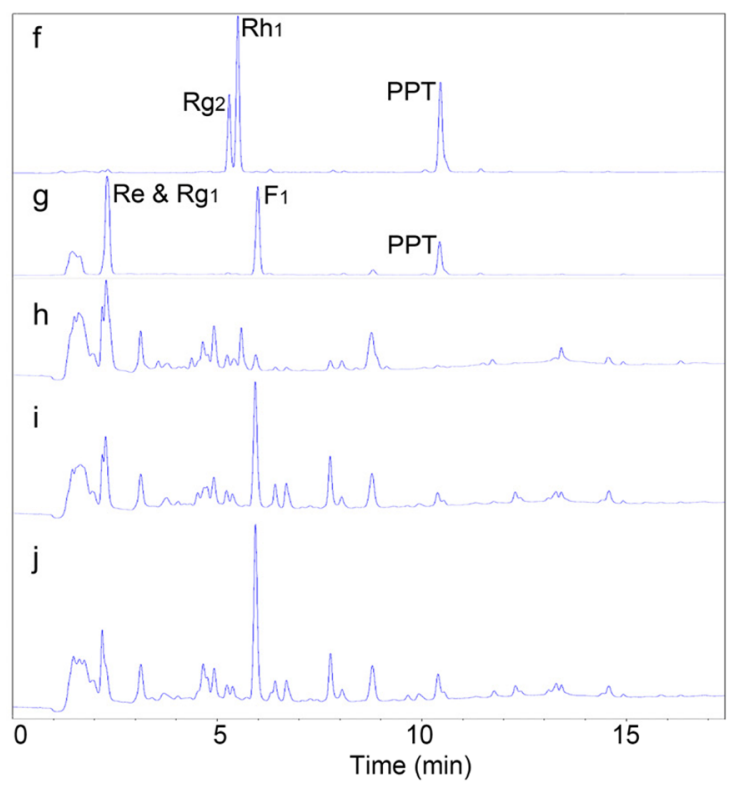

PPDGM. e CK produced after $24 \mathrm{~h}$ of reaction. f Ginsenoside standards $\left(\mathrm{Rg}_{2}, \mathrm{Rh}_{1}, \mathrm{PPT}\right)$. g Ginsenoside standards (Re, $\left.\mathrm{Rg}_{1}, \mathrm{~F}_{1}, \mathrm{PPT}\right)$. h PPTGM. i $F_{1}$ produced after $6 \mathrm{~h}$ of reaction of immobilized C3a-MT619 with PPTGM. $\mathbf{j} \mathrm{F}_{1}$ produced after $24 \mathrm{~h}$

C. glutamicum for applications in the food industry (Cheng et al. 2016; Shin et al. 2016b). However, the low expression levels of recombinant proteins in GRAS strains reduce their efficiency in the production processes.

One-step purification, concentration, and immobilization of enzymes using low-cost cellulosic materials would greatly facilitate enzyme preparation and decrease protein purification costs. Furthermore, cellulose has been used in various kinds of foods, such as traditional desserts, low cholesterol diets, vegetarian meats, and as additives, owing to their natural abundance, lack of toxicity, low cost, and intriguing mechanical properties (Eichhorn et al. 2009; Habibi et al. 2010; Je et al. 2017; Moon et al. 2011; Nishino et al. 2004; Wang et al. 2016; Youssef et al. 2016). This convenient and efficient immobilization method could also be usefully exploited in the preparation of food-processing recombinant enzymes in the functional food and cosmetic industries.

In conclusion, we describe the isolation of a ginsenosidehydrolyzing $\beta$-glucosidase (MT619), its heterologous expression in C. glutamicum ATCC13032, concentration and immobilization on RAC by protein-cellulose interactions, and the efficient production of $\mathrm{CK}$ and $\mathrm{F}_{1}$. Compared with traditional $\mathrm{CK}$ and $\mathrm{F}_{1}$ preparation methods using the $E$. coli host system, the expression level is decreased, but this method of immobilization and production offers a number of advantages. (1) A GRAS strain was used for enzyme preparation, which is effective for food processing. (2) The immobilization, purification, and concentration of the enzyme is a simple, one-step process with high capacity for supporting materials. (3) The supporting material, cellulose, is an environmentally friendly, 
sustainable biomaterial and is widely used as a food additive. (4) The high density and purity of the immobilized enzymes increased productivity substantially. Thus, our findings demonstrate that the concentrated and immobilized $\beta$-glucosidase that was heterologously expressed in $C$. glutamicum can be used to efficiently produce $\mathrm{CK}$ and $\mathrm{F}_{1}$ from crude material from ginseng extracts. We believe that this method will provide an alternative approach for the food-grade production of $\mathrm{CK}$ and $\mathrm{F}_{1}$, as core functional biomaterials in the health food industries.

Funding This work was supported by the Intelligent Synthetic Biology Center of Global Frontier Project (2011-0031957), Republic of Korea.

\section{Compliance with ethical standards}

Conflict of interest The authors declare that they have no conflict of interest.

Ethical approval This article does not contain any studies with animals or human participants performed by any of the authors.

Open Access This article is distributed under the terms of the Creative Commons Attribution 4.0 International License (http:// creativecommons.org/licenses/by/4.0/), which permits unrestricted use, distribution, and reproduction in any medium, provided you give appropriate credit to the original author(s) and the source, provide a link to the Creative Commons license, and indicate if changes were made.

\section{References}

An DS, Cui CH, Lee HG, Wang L, Kim S, Lee ST, Jin F, Yu H, Chin YW, Lee HK, Im WT, Kim SG (2010) Identification and characterization of a novel Terrabacter ginsenosidimutans sp. nov. $\beta$-Glucosidase that transforms ginsenoside $\mathrm{Rb}_{1}$ into the rare gypenosides XVII and LXXV. Appl Environ Microbiol 76:5827-5836. https://doi.org/10. 1128/AEM.00106-10

An DS, Cui CH, Siddiqi MZ, Yu HS, Jin FX, Kim SG, Im WT (2017) Gram-scale production of ginsenoside $\mathrm{F}_{1}$ using a recombinant bacterial $\beta$-glucosidase. J Microbiol Biotechnol 27:1559-1565. https:// doi.org/10.4014/jmb.1703.03006

Bothwell MK, Walker LP (1995) Evaluation of parameter estimation methods for estimating cellulase binding constants. Bioresour Technol 53:21-29. https://doi.org/10.1016/0960-8524(95)00046-H

Burdock GA, Carabin IG (2004) Generally recognized as safe (GRAS): history and description. Toxicol Lett 150:3-18. https://doi.org/10. 1016/j.toxlet.2003.07.004

Chen J, Wu H, Wang Q, Chang Y, Liu K, Wei W (2015) Ginsenoside metabolite Compound $\mathrm{K}$ suppresses T-cell priming via modulation of dendritic cell trafficking and costimulatory signals, resulting in alleviation of collagen-induced arthritis. J Pharmacol Exp Ther 353: 71-79. https://doi.org/10.1124/jpet.114.220665

Chen L, Zhou L, Huang J, Wang Y, Yang G, Tan Z, Wang Y, Zhou G, Liao J, Ouyang D (2017a) Single- and multiple-dose trials to determine the pharmacokinetics, safety, tolerability, and sex effect of oral ginsenoside compound $\mathrm{k}$ in healthy Chinese volunteers. Front Pharmacol 8(965). https://doi.org/10.3389/fphar.2017.00965

Chen L, Zhou L, Wang Y, Yang G, Huang J, Tan Z, Wang Y, Zhou G, Liao J, Ouyang D (2017b) Food and sex-related impacts on the pharmacokinetics of a single-dose of ginsenoside compound $\mathrm{k}$ in healthy subjects. Front Pharmacol 8(636). https://doi.org/10.3389/ fphar.2017.00636

Cheng F, Gong Q, Yu H, Stephanopoulos G (2016) High-titer biosynthesis of hyaluronic acid by recombinant Corynebacterium glutamicum. Biotechnol J 11:574-584. https://doi.org/10.1002/ biot.201500404

Cho SH, Chung KS, Choi JH, Kim DH, Lee KT (2009) Compound K, a metabolite of ginseng saponin, induces apoptosis via caspase-8dependent pathway in HL-60 human leukemia cells. BMC Cancer 9(449). https://doi.org/10.1186/1471-2407-9-449

Chung HS, Lee YC, Rhee YK, Lee SY (2011) Consumer acceptance of ginseng food products. J Food Sci 76:S516-S522. https://doi.org/ 10.1111/j.1750-3841.2011.02399.x

Cui CH, Kim SC, Im WT (2013) Characterization of the ginsenosidetransforming recombinant $\beta$-glucosidase from Actinosynnema mirum and bioconversion of major ginsenosides into minor ginsenosides. Appl Microbiol Biotechnol 97:649-659. https://doi. org/10.1007/s00253-012-4324-5

Cui CH, Kim JK, Kim SC, Im WT (2014) Characterization of a ginsenoside-transforming $\beta$-glucosidase from Paenibacillus mucilaginosus and its application for enhanced production of minor ginsenoside $\mathrm{F}_{2}$. PLoS One 9:e85727. https://doi.org/10.1371/ journal.pone.0085727

Cui L, Wu SQ, Zhao CA, Yin CR (2016) Microbial conversion of major ginsenosides in ginseng total saponins by Platycodon grandiflorum endophytes. J Gins Res 40:366-374. https://doi.org/10.1016/j.jgr. 2015.11.004

Cui CH, Kim DJ, Jung SC, Kim SC, Im WT (2017) Enhanced production of gypenoside LXXV using a novel ginsenoside-transforming $\beta$ glucosidase from ginseng-cultivating soil bacteria and its anticancer property. Molecules 22. https://doi.org/10.3390/ molecules22050844

Du J, Cui CH, Park SC, Kim JK, Yu HS, Jin FX, Sun C, Kim SC, Im WT (2014) Identification and characterization of a ginsenosidetransforming $\beta$-glucosidase from Pseudonocardia sp. Gsoil 1536 and its application for enhanced production of minor ginsenoside $\mathrm{Rg}_{2}(\mathrm{~S})$. PLoS One 9:e96914. https://doi.org/10.1371/journal.pone. 0096914

Eichhorn SJ, Dufresne A, Aranguren M, Marcovich NE, Capadona JR, Rowan SJ, Weder C, Thielemans W, Roman M, Renneckar S, Gindl W, Veigel S, Keckes J, Yano H, Abe K, Nogi M, Nakagaito AN, Mangalam A, Simonsen J, Benight AS, Bismarck A, Berglund LA, Peijs T (2009) Review: current international research into cellulose nanofibres and nanocomposites. J Mater Sci 45:1-33. https://doi. org/10.1007/s10853-009-3874-0

Gu J, Li W, Xiao D, Wei S, Cui W, Chen W, Hu Y, Bi X, Kim Y, Li J, Du H, Zhang M, Chen L (2013) Compound K, a final intestinal metabolite of ginsenosides, enhances insulin secretion in MIN6 pancreatic $\beta$-cells by upregulation of GLUT2. Fitoterapia 87:84-88. https:// doi.org/10.1016/j.fitote.2013.03.020

Ha J, Shim YS, Seo D, Kim K, Ito M, Nakagawa H (2013) Determination of 22 ginsenosides in ginseng products using ultra-highperformance liquid chromatography. J Chromatogr Sci 51:355360. https://doi.org/10.1093/chromsci/bms 148

Habibi Y, Lucia LA, Rojas OJ (2010) Cellulose nanocrystals: chemistry, self-assembly, and applications. Chem Rev 110:3479-3500. https:// doi.org/10.1021/cr900339w

Hong J, Ye X, Zhang YH (2007) Quantitative determination of cellulose accessibility to cellulase based on adsorption of a nonhydrolytic fusion protein containing CBM and GFP with its applications. Langmuir 23:12535-12540. https://doi.org/10.1021/la7025686

Hong J, Ye X, Wang Y, Zhang YH (2008) Bioseparation of recombinant cellulose-binding module-proteins by affinity adsorption on an ultrahigh-capacity cellulosic adsorbent. Anal Chim Acta 621:193-199. https://doi.org/10.1016/j.aca.2008.05.041 
Hou J, Cui C, Kim S, Sung C, Choi C (2018) Ginsenoside F suppresses astrocytic senescence-associated secretory phenotype. Chem Biol Interact 283:75-83. https://doi.org/10.1016/j.cbi.2018.02.002

Hu C, Song G, Zhang B, Liu Z, Chen R, Zhang H, Hu T (2012) Intestinal metabolite Compound $\mathrm{K}$ of panaxoside inhibits the growth of gastric carcinoma by augmenting apoptosis via Bid-mediated mitochondrial pathway. J Cell Mol Med 16:96-106. https://doi.org/10.1111/j. 1582-4934.2011.01278.x

Je HH, Noh S, Hong SG, Ju Y, Kim J, Hwang DS (2017) Cellulose nanofibers for magnetically-separable and highly loaded enzyme immobilization. Chem Eng J 323:425-433. https://doi.org/10. 1016/j.cej.2017.04.110

Kim YS, Yoo MH, Lee GW, Choi JG, Kim KR, Oh DK (2011) Ginsenoside $F_{1}$ production from ginsenoside $\operatorname{Rg}_{1}$ by a purified $\beta$ Glucosidase from Fusarium moniliforme var. subglutinans. Biotechnol Lett 33:2457-2461. https://doi.org/10.1007/s10529. 011-0719-0

Kim MS, Lee KT, Iseli TJ, Hoy AJ, George J, Grewal T, Roufogalis BD (2013) Compound K modulates fatty acid-induced lipid droplet formation and expression of proteins involved in lipid metabolism in hepatocytes. Liver Int 33:1583-1593. https://doi.org/10.1111/liv. 12287

Kumar S, Stecher G, Tamura (2016) K. MEGA7: molecular evolutionary genetics analysis version 7.0 for bigger datasets. Mol Biol Evol 33: 1870-1874. https://academic.oup.com/mbe/article/33/7/1870/ 2579089

Lee SY (2018) Synergistic effect of maclurin on ginsenoside Compound $\mathrm{K}$ induced inhibition of the transcriptional expression of matrix metalloproteinase-1 in HaCaT human keratinocyte cells. J Gins Res 42:229-232. https://doi.org/10.1016/j.jgr.2017.11.003

Lee EH, Cho SY, Kim SJ, Shin ES, Chang HK, Kim DH, Yeom MH, Woe KS, Lee J, Sim YC, Lee TR (2003) Ginsenoside $F_{1}$ protects human $\mathrm{HaCaT}$ keratinocytes from ultraviolet-B-induced apoptosis by maintaining constant levels of Bcl-2. J Invest Dermatol 121:607613. https://doi.org/10.1046/j.1523-1747.2003.12425.x

Lee BH, Hwang SH, Choi SH, Kim HJ, Lee JH, Lee SM, Ahn YG, Nah SY (2013) Inhibitory effects of ginsenoside metabolites, Compound $\mathrm{K}$ and protopanaxatriol, on $\mathrm{GABA}(\mathrm{C})$ receptor-mediated ion currents. Korean J Physiol Pharmacol 17:127-132. https://doi.org/10. 4196/kjpp.2013.17.2.127

Lee CS, Nam G, Bae IH, Park J (2018) Whitening efficacy of ginsenoside $\mathrm{F}_{1}$ through inhibition of melanin transfer in cocultured human melanocytes-keratinocytes and three-dimensional human skin equivalent. J Gins Res 43:300-304. https://doi.org/10.1016/j.jgr. 2017.12.005

Li L, Shin SY, Lee SJ, Moon JS, Im WT, Han NS (2016a) Production of ginsenoside $\mathrm{F}_{2}$ by Using Lactococcus lactis with enhanced expression of $\beta$-glucosidase gene from Paenibacillus mucilaginosus. J Agric Food Chem 64:2506-2512. https://doi.org/10.1021/acs.jafc. 5 b04098

Li M, Yue Y, Zhang ZJ, Wang ZY, Tan TW, Fan LH (2016b) Site-specific and high-loading immobilization of proteins by using cohesindockerin and CBM-cellulose interactions. Bioconjug Chem 27: 1579-1583. https://doi.org/10.1021/acs.bioconjchem.6b00282

Liu X, Yang Y, Zhang W, Sun Y, Peng F, Jeffrey L, Harvey L, McNeil B, Bai Z (2016) Expression of recombinant protein using Corynebacterium glutamicum: progress, challenges and applications. Crit Rev Biotechnol 36:652-664. https://doi.org/10.3109/ 07388551.2015 .1004519

Lv Y, Wu Z, Han S, Lin Y, Zheng S (2012) Construction of recombinant Corynebacterium glutamicum for L-threonine production. Biotechnol Biopro 17:16-21. https://doi.org/10.1007/s12257-011$0360-8$

Moon RJ, Martini A, Nairn J, Simonsen J, Youngblood J (2011) Cellulose nanomaterials review: structure, properties and nanocomposites. Chem Soc Rev 40:3941-3994. https://doi.org/10.1039/c0cs00108b
Nishino T, Matsuda I, Hirao K (2004) All-Cellulose Composite. Macromolecules 37:7683-7687. https://doi.org/10.1021/ ma049300h

Oliveira C, Carvalho V, Domingues L, Gama FM (2015) Recombinant CBM-fusion technology - applications overview. Biotechnol Adv 33:358-369. https://doi.org/10.1016/j.biotechadv.2015.02.006

Park CS, Yoo MH, Noh KH, Oh DK (2010) Biotransformation of ginsenosides by hydrolyzing the sugar moieties of ginsenosides using microbial glycosidases. Appl Microbiol Biotechnol 87:9-19. https://doi.org/10.1007/s00253-010-2567-6

Park HW, In G, Han ST, Lee MW, Kim SY, Kim KT, Cho BG, Han GH, Chang IM (2013) Simultaneous determination of 30 ginsenosides in Panax ginseng preparations using ultra performance liquid chromatography. J Gins Res 37:457-467. https://doi.org/10.5142/jgr.2013. 37.457

Qi LW, Wang CZ, Yuan CS (2010) American ginseng: potential structurefunction relationship in cancer chemoprevention. Biochem Pharmacol 80:947-954. https://doi.org/10.1016/j.bcp.2010.06.023

Qin M, Luo Y, Lu S, Sun J, Yang K, Sun G, Sun X (2017) Ginsenoside F 1 ameliorates endothelial cell inflammatory injury and prevents atherosclerosis in mice through A20-mediated suppression of NF-kB signaling. Front Pharmacol 8(953). https://doi.org/10.3389/fphar. 2017.00953

Ruan Y, Zhu L, Li Q (2015) Improving the electro-transformation efficiency of Corynebacterium glutamicum by weakening its cell wall and increasing the cytoplasmic membrane fluidity. Biotechnol Lett 37:2445-2452. https://doi.org/10.1007/s10529-015-1934-x

Shi Y, Sun C, Zheng B, Gao B, Sun A (2013) Simultaneous determination of ten ginsenosides in American ginseng functional foods and ginseng raw plant materials by liquid chromatography tandem mass spectrometry. Food Anal Methods 6:112-122. https://doi.org/10. 1007/s12161-012-9406-6

Shin KC, Oh DK (2016) Classification of glycosidases that hydrolyze the specific positions and types of sugar moieties in ginsenosides. Crit Rev Biotechnol 36:1036-1049. https://doi.org/10.3109/07388551. 2015.1083942

Shin KC, Choi HY, Seo MJ, Oh DK (2016a) Compound K Production from Red Ginseng Extract by $\beta$-Glycosidase from Sulfolobus solfataricus Supplemented with $\alpha$-L-Arabinofuranosidase from Caldicellulosiruptor saccharolyticus. PLoS One 10:e0145876. https://doi.org/10.1371/journal.pone.0145876

Shin KC, Sim DH, Seo MJ, Oh DK (2016b) Increased production of food-grade d-tagatose from d-galactose by permeabilized and immobilized cells of Corynebacterium glutamicum, a GRAS host, expressing d-galactose isomerase from Geobacillus thermodenitrificans. J Agric Food Chem 64:8146-8153. https:// doi.org/10.1021/acs.jafc.6b03588

Shin KC, Choi HY, Seo MJ, Oh DK (2017) Improved conversion of ginsenoside $\mathrm{Rb}_{1}$ to Compound $\mathrm{K}$ by semi-rational design of Sulfolobus solfataricus $\beta$-glycosidase. AMB Express 7(186):186. https://doi.org/10.1186/s13568-017-0487-x

Shire SJ, Shahrokh Z, Liu J (2004) Challenges in the development of high protein concentration formulations. J Pharm Sci 93:1390-1402. https://doi.org/10.1002/jps.20079

Siddiqi MZ, Cui CH, Park SK, Han NS, Kim SC, Im WT (2017) Comparative analysis of the expression level of recombinant ginsenoside-transforming $\beta$-glucosidase in GRAS hosts and mass production of the ginsenoside $\mathrm{Rh}_{2}$-Mix. PLoS One 12:e176098. https://doi.org/10.1371/journal.pone.0176098

Smith I, Williamson EM, Putnam S, Farrimond J, Whalley BJ (2014) Effects and mechanisms of ginseng and ginsenosides on cognition. Nutr Rev 72:319-333. https://doi.org/10.1111/nure.12099

Song MY, Kim BS, Kim H (2014) Influence of Panax ginseng on obesity and gut microbiota in obese middle-aged Korean women. J Gins Res 38:106-115. https://doi.org/10.1016/j.jgr.2013.12.004 
Sun BS, Gu LJ, Fang ZM, Wang CY, Wang Z, Lee MR, Li Z, Li JJ, Sung CK (2009) Simultaneous quantification of 19 ginsenosides in black ginseng developed from Panax ginseng by HPLC-ELSD. J Pharm Biomed Anal 50:15-22. https://doi.org/10.1016/j.jpba.2009.03.025

Wan JB, Zhang QW, Ye WC, Wang YT (2008) Quantification and separation of protopanaxatriol and protopanaxadiol type saponins from Panax notoginseng with macroporous resins. Sep Purif Technol 60: 198-205. https://doi.org/10.1016/j.seppur.2007.08.007

Wang CW, Huang YC, Chan FN, Su SC, Kuo YH, Huang SF, Hung MW, Lin HC, Chang WL, Chang TC (2015) A gut microbial metabolite of ginsenosides, Compound $\mathrm{K}$, induces intestinal glucose absorption and $\mathrm{Na}^{+} /$glucose cotransporter 1 gene expression through activation of cAMP response element binding protein. Mol Nutr Food Res 59: 670-684. https://doi.org/10.1002/mnfr.201400688

Wang S, Lu A, Zhang L (2016) Recent advances in regenerated cellulose materials. Prog Polym Sci 53:169-206. https://doi.org/10.1016/j. progpolymsci.2015.07.003

Wei S, Li W, Yu Y, Yao F, A L, Lan X, Guan F, Zhang M, Chen L (2015) Ginsenoside Compound $\mathrm{K}$ suppresses the hepatic gluconeogenesis via activating adenosine-5'monophosphate kinase: A study in vitro and in vivo. Life Sci 139:8-15. https://doi.org/10.1016/j.lfs.2015. 07.032

Wong AS, Che CM, Leung KW (2015) Recent advances in ginseng as cancer therapeutics: a functional and mechanistic overview. Nat Prod Rep 32:256-272. https://doi.org/10.1039/c4np00080c

Yang XD, Yang YY, Ouyang DS, Yang GP (2015) A review of biotransformation and pharmacology of ginsenoside Compound $\mathrm{K}$. Fitoterapia 100:208-220. https://doi.org/10.1016/j.fitote.2014.11. 019

Yim SS, An SJ, Choi JW, Ryu AJ, Jeong KJ (2014) High-level secretory production of recombinant single-chain variable fragment $(\mathrm{scFv})$ in Corynebacterium glutamicum. Appl Microbiol Biotechnol 98:273284. https://doi.org/10.1007/s00253-013-5315-x

You C, Zhang YH (2013) Self-assembly of synthetic metabolons through synthetic protein scaffolds: one-step purification, co-immobilization, and substrate channeling. ACS Synth Biol 2:102-110. https:// doi.org/10.1021/sb300068g
Youssef AM, El Sayed SM, El Sayed HS, Salama HH, Dufresne A (2016) Enhancement of Egyptian soft white cheese shelf life using a novel chitosan/carboxymethyl cellulose/zinc oxide bionanocomposite film. Carbohydr Polym 151:9-19. https://doi.org/10.1016/j. carbpol.2016.05.023

Yu X, Sun J, Wang W, Jiang L, Wang R, Xiao W, Cheng B, Fan J (2017) Tobacco etch virus protease mediating cleavage of the cellulosebinding module tagged colored proteins immobilized on the regenerated amorphous cellulose. Bioprocess Biosyst Eng 40:1101-1110. https://doi.org/10.1007/s00449-017-1772-4

Zhang W, Sun Z (2008) Random local neighbor joining: a new method for reconstructing phylogenetic trees. Mol Phylogenet Evol 47:117$128 \mathrm{https}: / / \mathrm{www} . \mathrm{sciencedirect.com/science/article/pii/}$ S1055790308000419

Zhao Y, Chen B, Yao S (2007) Separation of 20(S)-protopanaxdiol type ginsenosides and 20(S)-protopanaxtriol type ginsenosides with the help of macroporous resin adsorption and microwave assisted desorption. Sep Purif Technol 52:533-538. https://doi.org/10.1016/j. seppur.2006.06.008

Zhou SS, Xu JD, Zhu H, Shen H, Xu J, Mao Q, Li SL, Yan R (2014) Simultaneous determination of original, degraded ginsenosides and aglycones by ultra high performance liquid chromatography coupled with quadrupole time-of-flight mass spectrometry for quantitative evaluation of Du-Shen-Tang, the decoction of ginseng. Molecules 19:4083-4104. https://doi.org/10.3390/molecules19044083

Zhou L, Chen L, Wang Y, Huang J, Yang G, Tan Z, Wang Y, Liao J, Zhou G, Hu K, Li Z, Ouyang D (2018) Impact of NR1I2, ABC transporters genetic polymorphisms on the pharmacokinetics of ginsenoside Compound $\mathrm{K}$ in healthy Chinese volunteers. J Gins Res. https://doi.org/10.1016/j.jgr.2018.04.003

Publisher's note Springer Nature remains neutral with regard to jurisdictional claims in published maps and institutional affiliations. 